Proc. Estonian Acad. Sci. Biol. Ecol., 2002, 51, 2, 138-144

\title{
The lack of old-growth forest - a threat to Estonian biodiversity
}

\begin{abstract}
Asko Lõhmus
Institute of Zoology and Hydrobiology, University of Tartu, Vanemuise 46, 51014 Tartu, Estonia; hirundo@linnu.tartu.ee

Received 22 October 2001

Abstract. Between 1997 and 2000, forest structure was studied in random plots in a 900-km² area in east-central Estonia. Only $2.4 \%$ (1.2\% outside reserves) of forest land was covered by old unmanaged multi-cohort forests or forests with gap-phase dynamics, and $28 \%$ of their area was situated in edge zones. No stands naturally recovering after a recent natural stand-replacing disturbance were found. Hence, Estonian forest landscapes seem to lack habitats for old-growth specialists, and restoration of natural structure of forests may be needed for the viability of the most sensitive species.
\end{abstract}

Key words: conservation, extinction threshold, forest edge, natural forests, Estonia.

\section{INTRODUCTION}

Intensive forest management is likely to cause habitat loss for many species, especially those requiring the conditions or structures of old growth (old trees, coarse woody debris, natural cavities etc.; recent reviews by Samuelsson et al., 1994; Esseen et al., 1997; Hunter, 1999). Habitat loss reduces population viability, but in at least some species not linearly - extinction risk increases sharply after a certain amount of habitat is gone (Lande, 1987; Noon \& McKelvey, 1996; With \& King, 1999). Therefore, the extent of habitat loss as well as the amount, quality, and pattern of remaining patches should be considered in any effort to sustain viable populations in managed landscapes.

The current availability of old forest is not sufficient for old-growth species in Fennoscandia (especially in the south) and these taxa are likely to become extinct unless additional reserves are established and extensive areas restored (Virkkala, 1996; Hanski, 2000; Angelstam \& Andersson, 2001). In contrast, the Baltic and 
East European countries are believed to have a more favourable situation for forest biota (Angelstam et al., 1997; Mikusiński \& Angelstam, 1997). Theoretically, viable populations of sensitive species in these countries could become sources for their re-establishment in Fennoscandia or Western Europe, after the habitat is improved there. However, it is also possible that intensifying forestry will destroy the natural forests of the Baltic and East European countries before that. To my knowledge, no current assessments of the conservation value of the Baltic forests are available.

In this paper, I summarize a randomized field survey of forest structure in a typical Estonian landscape. The aim was to check whether the loss of old-growth exceeds theoretical thresholds of extinction and to compare the results with those from Fennoscandia. In addition to internal structure, which is among the best 'shortcuts' for evaluating natural state of forests (Lindholm \& Tuominen, 1993), I also assessed the distances of forest areas to forest edges and roads, which are known to have negative impacts on many taxa, for example due to changes in microclimate, invasions of alien species, or human disturbance (Matlack \& Litvaitis, 1999; Lugo \& Gucinski, 2000).

\section{MATERIAL AND METHODS}

\section{Study area}

The study was carried out in nine adjacent UTM-grid squares (ME3: b1-b3, $\mathrm{c} 1-\mathrm{c} 4, \mathrm{~d} 2, \mathrm{~d} 3 ; 100 \mathrm{~km}^{2}$ each) in east-central Estonia $\left(58^{\circ} 25^{\prime} \mathrm{N}, 26^{\circ} 20^{\prime} \mathrm{E}\right)$, totalling $900 \mathrm{~km}^{2}$ in area with random borders (over $2 \%$ of Estonian land area). The area includes different forestry units (six state forest districts as well as a large number of private owners), and was initially established by local birdwatching tradition not related to specific habitats. Therefore, its forests should reflect the management regimes typical of Estonia. However, $15 \%$ of the territory (23\% of forest land) is covered by recently (1994) established Alam-Pedja Nature Reserve, which has been treated separately from the sites outside it.

Forest land covers $40 \%$ of the area, mires $8 \%$, flood-plains $7 \%$, rivers and lakes $2 \%$, and settlements $6 \%$, the remaining $37 \%$ being mostly open agricultural landscape. Of the forests $50 \%$ grow on wet soils. Tree layers consist of birch Betula spp. (46\% on average), Scots pine Pinus sylvestris (17\%), Norway spruce Picea abies (15\%), aspen Populus tremula (9\%), white alder Alnus incana (7\%), black alder A. glutinosa (6\%), and other tree species (1\%) (all data from the analysis of random plots, see below). Thus, the general landscape composition is very similar to the Estonian average (dominated by about $44 \%$ of forest land and $35 \%$ of agricultural land; Raukas, 1995), although the forests contain more birch and fewer coniferous trees (Anon., 2000). 


\section{Field methods}

The area was described in the field in 1997-2000 by randomly establishing 1800 plots (200 plots per each UTM-grid square). The forest data represent generally the situation in 1997-98, since in the last two years the forests of the unmanaged Alam-Pedja Nature Reserve were described.

Forest was defined as a stand at least $50 \mathrm{~m}$ from the nearest house, where the maximum crown coverage of trees within $5 \mathrm{~m}$ from the plot centre was at least $0.3(30 \%)$. By structure, forests were classified into four categories: (1) plantations, young or middle-aged secondary forests with even-aged trees, all stands with signs of recent (during the last 10-15 years) logging; (2) middle-aged or old secondary stands where multiple canopy layers have started to develop, no signs of recent management, well-decayed logs present; (3) old multi-cohort forest where at least $5 \%$ of trunks are dead, over $10 \%$ of logs well-decayed, no signs of recent management, but no established gap dynamics either; (4) old forest with gap-phase dynamics (canopy gaps of different sizes and different stages of regeneration) and no signs of management. Recently established drainage systems within $50 \mathrm{~m}$ were always classified as 'signs of management'. The impact of old ditches was assessed individually for all (potential) category (2-4) forests, resulting in that no drained forests were classified as category (4), but some were (by their natural structure) included into category (3). In principle, natural regeneration phases that follow natural stand-replacing disturbances should have been also considered, but such stands were not found.

Forest edge was defined as the transition between forest and non-forest. If the transition was not abrupt, for example where forest was bordered by wooded mire, the nearest opening of at least $30 \mathrm{~m}$ in diameter or the edge between wooded and shrubby area (whatever was closest) were considered. Most distances to forest edges were checked in the field, and maps or aerophotos were completely relied upon only in the case of distant edges (several hundreds of meters away). In managed forests, field measurements were the only reliable method because edges changed quickly there.

\section{RESULTS}

On average, $2.4 \%$ of the forest land was covered with old unmanaged multicohort forests or forests with gap-phase dynamics (Table 1). This percentage reached 6.4 in the Alam-Pedja Nature Reserve but was only $1.2 \%$ outside it $\left(\chi^{2}=14.7, \mathrm{df}=1, p<0.001\right)$. Forests with natural stand-level disturbance regimes were extremely rare, for example no stands naturally recovering after a recent natural stand-replacing disturbance (fire, large-scale windthrow) were found. Gap dynamics was recorded in seven plots $(0.95 \%$ of the forest land), one of which had been recently logged. Some structures of old growth occurred also in several stands of categories (1) or (2). For example, 16 such stands (2.2\% of forest land) 
Table 1. Composition of forest land by stand structure in east-central Estonia

\begin{tabular}{l|c|c|c|c|c|c}
\hline \multirow{2}{*}{ Area } & \multirow{2}{*}{$\begin{array}{c}\text { No. of } \\
\text { plots }\end{array}$} & \multicolumn{5}{|c}{ Composition of forest land (\%) by stand structure } \\
\cline { 3 - 7 } & studied & Clearcut & $(1)^{\mathrm{a}}$ & $(2)^{\mathrm{a}}$ & $(3)^{\mathrm{a}}$ & $(4)^{\mathrm{a}}$ \\
\hline \multirow{2}{*}{ Nature reserve } & 171 & 4.7 & 61.4 & 27.5 & 4.1 & 2.3 \\
Outside reserve & 562 & 15.8 & 72.2 & 10.7 & 1.2 & 0.0 \\
$\quad$ Total & 733 & 13.2 & 69.7 & 14.6 & 1.9 & 0.5
\end{tabular}

a Stand types: (1) plantations, young or middle-aged secondary stands, recently logged even-aged stands; (2) middle-aged or old single-cohort secondary stands with no signs of recent management; (3) old multi-cohort stands without gap dynamics; (4) old unmanaged stands with gap-phase dynamics.

had over $10 \%$ of all trunks as logs, including at least some from the latest decay stages (soft wood), and 8 plots (1.1\%) had a similar amount of snags.

Outside the Alam-Pedja Nature Reserve, $95 \%$ of the forest land $(n=562$ plots) was situated within $1 \mathrm{~km}$ of the nearest road, and the stand structure was well related to distance, with recent clearcuts closer and forests of categories (3) and (4) more distant from roads (Fig. 1; Gamma correlation: $\Gamma=0.15, p<0.001$ ). Naturalness of stand was not significantly correlated with other characteristics of human presence, such as distances from houses $(\Gamma=0.05, p>0.20)$, permanently used roads $(\Gamma=0.08, p>0.05)$, or agricultural lands $(\Gamma=-0.01, p>0.20)$.

Of the plots $65 \%$ were situated less than $200 \mathrm{~m}$ from an edge (Fig. 2) and $22 \%$ were situated within the edge zone (distance that equals the double forest height).

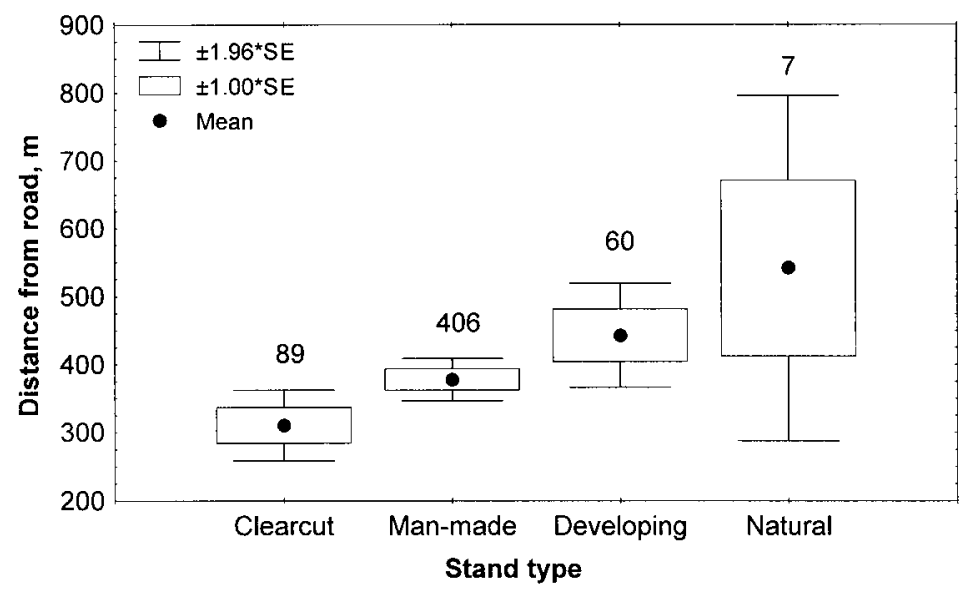

Fig. 1. Stand types outside the reserve in relation to distance from road. The numbers above boxes denote sample sizes. 'Man-made' stands correspond to category (1), 'developing' to category (2), and 'natural' to categories (3) and (4) (see Material and Methods for details). 


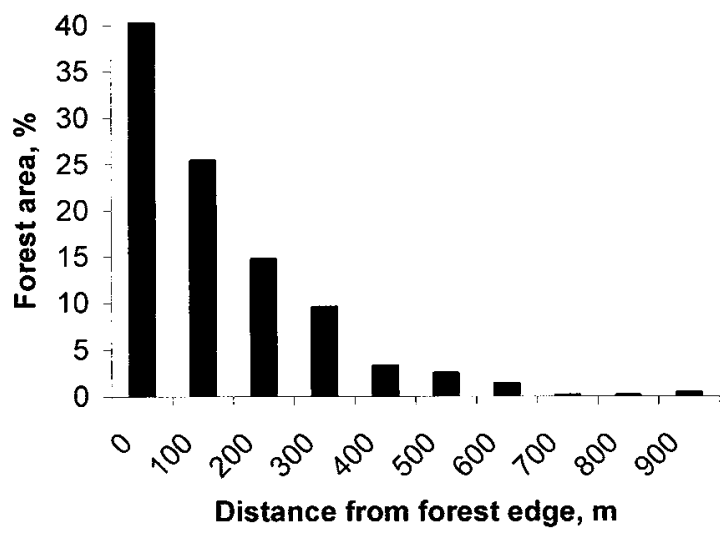

Fig. 2. Forest area relative to distance from nearest forest edge in east-central Estonia $(n=624$ random plots).

Only $32 \%$ of the nearest edges $(n=634)$ were natural (outside the reserve, only $21 \%, n=472)$; the other main edge types being clearcuts (36\% in total, $42 \%$ outside the reserve) and agricultural lands (31\% and $37 \%$, respectively). Half of the 18 plots of category (3) or (4) stands were situated less than $200 \mathrm{~m}$ from an edge, and five (28\%) were situated within the edge zone.

\section{DISCUSSION}

The percentage of old unmanaged multi-cohort forests or forests with gapphase dynamics outside the reserve was remarkably low (1.2\%), but similar to the preliminary results of the Estonian key-habitat inventory (1.5\%; R. Martverk and L. Andersson, pers. comm.). Even if all strict reserves had over $6 \%$ of their forest lands with natural structure as in the Alam-Pedja Nature Reserve (highly unrealistic; the real percentage can be as low as 3.5\%; Viilma et al., 2001), such forests would cover less than $2 \%$ of Estonian forest land. This is comparable to the 1\% of natural forests left in Fennoscandia (Gustafsson, 2000; Hanski, 2000). Even the road network was nearly as dense: while in southern Sweden $98 \%$ of all forest land lies within $1 \mathrm{~km}$ to the nearest road (Esseen, 1997), the respective proportion was $95 \%$ outside the reserve in the Estonian study area.

The 2\%-coverage of natural forests in Estonia is well below the critical threshold of remaining original habitat for specialist species (a tentative estimate: 20\%; Angelstam \& Andersson, 2001). Moreover, a significant part of the existing natural stands are situated in the edge zone and can be unsuitable for interior species, sensitive to fluctuations in microclimate or to negative interactions with other species (see Matlack \& Litvaitis, 1999). Hence the Estonian forest landscapes seem to lack valuable stands for old-growth specialists and restoration 
of a natural structure may be needed for the viability of these species. Such remnant populations can also hardly serve as sources for other countries. It is not clear to what extent this situation results from the intensified forestry of the $1990 \mathrm{~s}$, but the very high percentage (15.8) of non-forested clearcuts seems to reflect at least partly the recent fate of Estonian natural forests. Currently stands with a natural structure persist only far from roads.

On the other hand, middle-aged or old secondary forests with a developing natural structure still cover extensive areas (over $25 \%$ of the forest land in the reserve, over $10 \%$ outside). There is an urgent need to study the differences between these stands and those with currently natural structure, and whether and how quickly they will become inhabited by sensitive taxa. Probably protection of these developing stands is the most effective way to fill the gaps in the current amount of natural forest in Estonia.

\section{ACKNOWLEDGEMENTS}

I thank Raivo Mänd and two anonymous referees for commenting on the first drafts of the manuscript.

\section{REFERENCES}

Angelstam, P. \& Andersson, L. 2001. Estimates of the needs for forest reserves in Sweden. Scan. J. For. Res., Suppl., 3, 38-51.

Angelstam, P., Anufriev, V., Balciauskas, L., Blagovidov, A., Borgegård, S.-O., Hodge, S., Majewski, P., Shvarts, E., Tishkov, A., Tomialojc, L. \& Wesolowski, T. 1997. Biodiversity and sustainable forestry in European forests - how west and east can learn from each other. Wildl. Soc. Bull., 25, 38-48.

Anon. 2000. Eesti metsad 1999. OÜ Eesti Metsakorralduskeskus, Tallinn.

Esseen, P. A., Ehnström, B., Ericson, L. \& Sjöberg, K. 1997. Boreal forests. Ecol. Bull., 46, 16-47.

Gustafsson, L. 2000. Red-listed species and indicators: vascular plants in woodland key habitats and surrounding production forest in Sweden. Biol. Conserv., 92, 35-43.

Hanski, I. 2000. Extinction debt and species credit in boreal forests: modelling the consequences of different approaches to biodiversity conservation. Ann. Zool. Fenn., 37, 271-280.

Hunter, M. L., Jr. (ed.) 1999. Maintaining Biodiversity in Forest Ecosystems. Cambridge Univ. Press.

Lande, R. 1987. Extinction thresholds in demographic models of territorial populations. Am. Nat., 130, 624-635.

Lindholm, T. \& Tuominen, S. 1993. Metsien puuston luonnontilaisuuden arviointi. Metsähallituksen luonnonsuojelujulkaisuja, Sarja A, No 3. Vantaa, Finland.

Lugo, A. E. \& Gucinski, H. 2000. Function, effects, and management of forest roads. For. Ecol. Manage., 133, 249-262.

Matlack, G. R. \& Litvaitis, J. A. 1999. Forest edges. In Maintaining Biodiversity in Forest Ecosystems (Hunter, M. L., Jr., ed.), pp. 210-233. Cambridge Univ. Press.

Mikusiński, G. \& Angelstam, P. 1997. European woodpeckers and anthropogenic habitat change. Vogelwelt, 118, 277-283. 
Noon, B. R. \& McKelvey, K. S. 1996. A common framework for conservation planning: linking individual and metapopulation models. In Metapopulations and Wildlife Conservation (McCullough, D. R., ed.), pp. 139-165. Island Press, Washington, D. C.

Raukas, A. (ed.) 1995. Eesti. Loodus. Valgus \& Eesti Entsüklopeediakirjastus, Tallinn.

Samuelsson, J., Gustafsson, L. \& Ingelög, T. 1994. Dying and Dead Trees - a Review of Their Importance for Biodiversity. Swedish Threatened Species Unit, Uppsala.

Viilma, K., Öövel, J., Tamm, U., Tomson, P., Amos, T., Ostonen, I., Sørensen, P. \& Kuuba, R. 2001. Estonian Forest Conservation Area Network. Final Report of the Estonian Forest Conservation Area Network Project. Triip Grupp, Tartu.

Virkkala, R. 1996. Metsien suojelualueverkon rakenne ja kehittämistarpeet - ekologinen lähestymistapa. Suomen Ympäristö 16, Helsinki.

With, K. A. \& King, A. W. 1999. Extinction thresholds for species in fractal landscapes. Conserv. Biol., 13, 314-326.

\title{
Vanade metsade vähesus - oht Eesti bioloogilisele mitmekesisusele
}

\begin{abstract}
Asko Lõhmus
Aastatel 1997-2000 kirjeldati Kesk-Eesti idaosas $900 \mathrm{~km}^{2}$ suurusel alal metsade struktuuri juhuslikult valitud proovialadel. Loodusliku struktuuriga vanad metsad (erivanuselised ja häilude dünaamikaga) katsid vaid 2,4\% metsamaast (väljaspool kaitsealasid 1,2\%) ja sellestki pindalast $28 \%$ paiknes servavööndis. Looduslike häiringute mõjul hävinud taastuvaid metsaalasid ei leitud. Võrdlus populatsioonide elujõulisuseks vajalike künnistega näitab, et Eesti metsamaastikes on ebapiisavalt elupaiku vanadele metsadele spetsialiseerunud liikide jaoks ning kõige tundlikumate liikide elujõulisuse säilitamiseks võib olla vajalik metsade loodusliku struktuuri taastamine.
\end{abstract}

